\title{
Culture: National, Organizational And Occupational: The Case Of Honda Of America Manufacturing, Inc.
}

Victoria L. Figiel, (E-mail: figiel@nova.edu), Nova Southeastern University

\begin{abstract}
This paper examines the merging of cultures at Honda of America Manufacturing at Marysville, Ohio in light of academic studies of international business and organizational behavior. At the heart of this review are studies of organizational behavior and personnel management revolving around national culture, organizational culture and occupational culture. Competing theories are explained. Application to the case of Honda of America Manufacturing provides a means of reviewing the academic discussion in a business environment where national cultures are merged.
\end{abstract}

\section{Introduction}

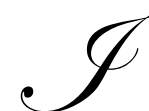

n Marysville, Ohio, USA, one auto manufacturing company has a new strategy to reach the top of the industry. It's called BN20: better in the next 20 years (Zachary, 2002). The company is not new to Marysville, since it marked 20 years of building cars there in November 2002 (Chappell, 2002, November 11). It is Honda of America Manufacturing.

Honda's Marysville plant is the oldest American plant and has the largest annual capacity of 440,000 units (Zachary, 2002). Honda's North American plants are among the highest in efficiency and flexibility, but an ethic of constant improvement and a vision for the future means more efficiency and flexibility is needed (Chappell, 2002, September 23).

Given the mixing of national cultures, how has Honda America managed to run more efficiently and more profitably than the big three (Chappell, 2002, August 5)? What is the culture of the organization that supports such success?

The purpose of this paper is to examine the merging of national cultures at Honda of America Manufacturing at Marysville, Ohio in light of academic studies of international business and organizational behavior. At the heart of this review are studies centering on national culture, organizational culture and occupational culture. Research questions for further study are offered.

\section{Culture: Definition, Levels, and Socialization}

First, a definition of culture is in order, followed by a review of the socialization process. The next step is to examine the theories of culture in light of the Honda of America case, specifically the principles of national, organizational and occupational culture.

\section{Culture: Theory and Development}

Hofstede and Pederson (1999, p.416) state that "Culture is the way you were brought up. It determines what constitutes proper behavior: in other words, the rules of the social game." Culture is tied to an individual's place of socialization which results in certain values or practices that become the norm for the nation's inhabitants, an organization's employees, or members of a specific occupation (Hofstede, Neuijen, Ohayv, \& Sanders, 1990). 
Figure 1 shows the levels of cultural differences as proposed by Hofstede, et al. (1990, p. 312): national, occupational, and organizational. The process of acculturation is accomplished through exposure to family, school and workplace. The processes acquired in childhood produce the deepest, hardest to change, cultural attitudes. Therefore, the place of socialization contributes to the level of cultural differentiation (Hofstede, et al., 1990).

Figure 1. Cultural differences: Level and socialization (Hofstede, et al., 1990, p. 312).

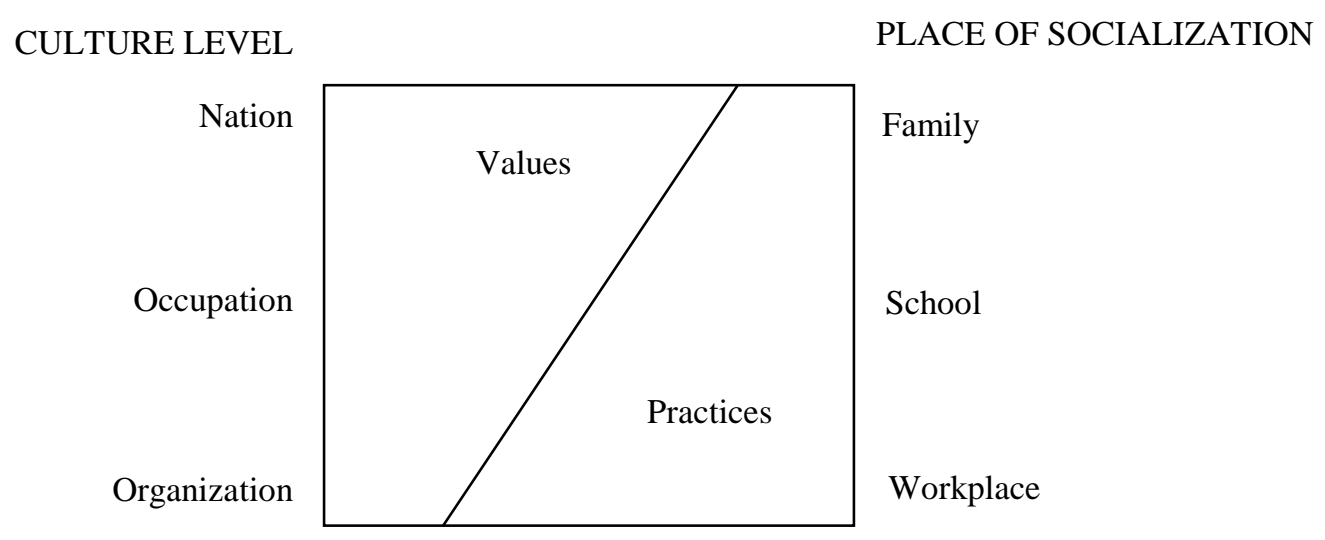

Figure 1 denotes three levels of culture, but further work by Hofstede suggests another cultural division: psychological culture (Hofstede, Bond, \& Luk, 1993). Psychological culture, existing in the mind of individuals, accounts for the way that an individual experiences the organizational culture.

Culture: Honda of America Manufacturing, Inc.

The psychological culture of the leadership at Honda of America would be difficult to assess without specific profiles, but their place of socialization provides insight to their cultural values (Hofstede, et al., 1990). Therefore, information relative to the place of socialization is used throughout the paper as an indicator of values. Kuchinke (1999. p. 135) goes further in stating, "Cultural values are important to leadership behavior."

Men born and socialized in Japan have held the highest rank at Honda of America Mfg. At the time of Lawrence Miller's visit to Marysville (Miller, 1991), Shoichiro Irimajiri was president, but in 1988, Hiroyuki Yoshino replaced him (Risen, 1988; Financial Times Information 2002). In 1998, Mr. Yoshino moved on to become the fifth president and CEO of Honda Motor Company (Financial Times Information, 2002). Today, the top post at Honda of America Mfg. is held by Koki Hirashima (Business Company Resource Center, 2003). Therefore, socialization and identification with Japanese culture is expected to influence Honda from the very top.

\section{Manifestations of Culture: Practices versus Values}

How though does the population of a country, organization, or work group exhibit culture? Observable phenomena become the outward manifestation of culture; be that national, organizational or occupational.

\section{Theory Basis for Cultural Manifestations}

Hofstede, et al. (1990) classified four categories to describe the manifestations of culture: symbols, heroes, rituals and values. Symbols are the words, gestures and objects that have meaning within a culture. Heroes, real or imaginary, alive or dead, serve as models of behavior in the culture. Although superfluous, rituals are the group 
activities performed for social reasons. Values, on the other hand, are feelings culturally defined in broad terms, such as pretty or ugly.

The first three manifestations of culture: symbols, heroes and rituals, are described as parts of cultural practice (Hofstede, et al., 1990). The practice is visible to observers but the perception of the cultural insider provides the meaning. The core of culture, Hofstede argues, is formed by values that cannot be observed but are apparent only through variable forms of behavior.

Figure 2 shows the four manifestations of culture. The outer ring is representative of the more superficial beliefs, and deeper rings being indicative of a core belief base (Hofstede, et. al, 1990). The outer rings of symbols, heroes and rituals come to have meaning through the practices that a culture gives to them.

Figure 2. Manifestations of culture: Values and practices (Hofstede, et al., 1990, p. 291).

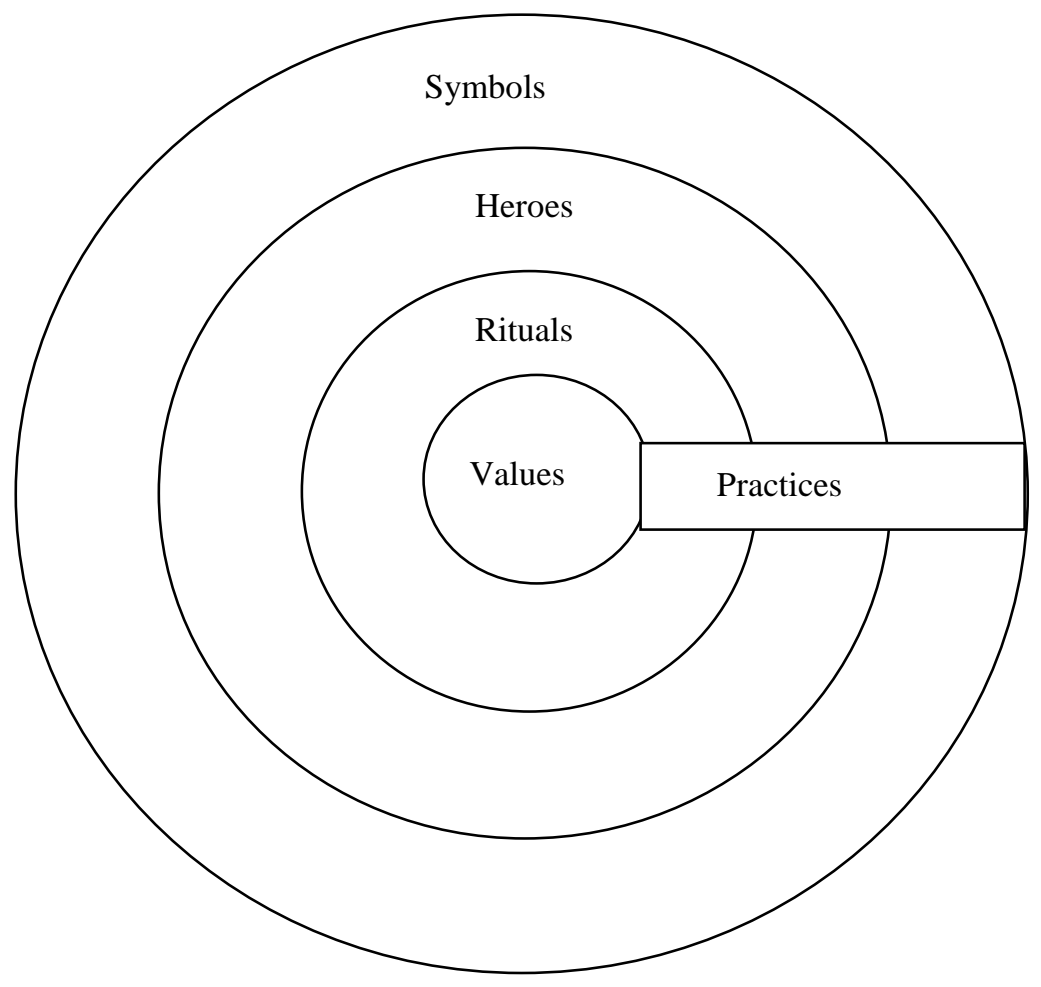

Symbols at Honda of America Mfg.

Lawrence Miller wrote in his case on Honda of America Mfg. (Miller, 1991) about employees wearing white smocks with the Honda name. The smocks serve as symbols of equality among employees and promote a shared investment in common goals. Symbols of equality are also apparent through the arrangement of furniture at Maryville. Desks are arranged in open areas in blocks of six with managers and from Japan and America sitting together. The cafeteria and parking spaces do not offer preferential opportunities for higher management, but management participates with the workers. 
One of the newer symbols at Honda of America is "BN20". Denoting "better in the next 20 years" (Zachary, 2002), "BN20" quickly communicates both a sense of history in Honda's successful 20 years at Marysville and the company's vision of increased flexibility and efficiency in manufacturing for the future. Lawrence Miller (1991) writes that "symbols are consistent with the philosophy." Every employee knows the company philosophy because it is apparent in hundreds of ways and through consistent messages from their leaders.

\section{Rituals at Honda of America}

At Marysville, new employees participate in the ritual of planting trees on the plant property to symbolize their personal growth with the company (Miller, 1991). Management and workers, alike, share the cafeteria and undesignated parking spaces. Every employee cleans his or her own work area. Each employee meets with the team at 6:30 to discuss the past day's events and expectations for the coming day. These rituals meet Hofstede's definition for group activities performed for social reasons within the culture (Hofstede, et al., 1990).

\section{Heroes at Honda of America}

Mr. Irimajiri tells of his encounter with Mr. Honda during a failed racing attempt in Lawrence Miller's case (Miller, 1991). Stories like these build heroes of not only Mr. Honda, but also Mr. Irimajiri.

\section{National Culture}

This section looks at the theory and dimensions of national culture. Secondly, this section reviews the case of Honda of America as a means of viewing the concepts of national culture in practice.

\section{Theory and National Culture}

"National culture is embedded deeply in everyday life and is relatively impervious to change" (Newman \& Nollen, 1996, p.754). National culture theory becomes one descriptor of human behavior. According to Hofstede (1980), national culture distinguishes the inhabitants of one country from those in another. Hofstede's national culture theory defines five national culture elements to describe the preferences for certain behaviors by a country's inhabitants.

\section{Five Dimensions of National Culture}

The dimensions of national culture originally appeared in 1980 from work Hofstede did with IBM's worldwide employees (Hofstede, 1980). Many since have expanded the research (Newman \& Nollen, 1996; Schuler \& Rogovsky, 1998; Kuchinke, 1999). Hofstede (1980; 1988) determined that each national culture could be classified based on five dimensions: 1) power distance, 2) individualism versus collectivism, 3) achievementorientation versus cooperation-orientation, 4) uncertainty avoidance versus uncertainty tolerance, and 5) long-term versus short-term orientation. While the dimensions can be used to categorize differences among national cultures, Hofstede specifically stated that valuing one observation as better than another was not appropriate.

Power distance dimension. Power distance indicates the degree to which some individuals are socially expected to exhibit power, status or privilege characteristics (Hofstede \& Pedersen, 1999). Japan is scored as a large power distance country while the United States is scored as a small power distance country in Hofstede's (1980) previous work.

Individualism dimension. Individualism versus collectivism is also known as low-context versus high-context (Ting-Toomey, 1989). As implied, this element represents a reference to the primary unit of identity as the individual or group (Hofstede \& Pedersen, 1999). Anglo countries, like the United States, are very high individualistic cultures and East Asian countries are very collective cultures (Hofstede, 1980; Newman \& Nollen, 1996). 
Achievement dimension. The achievement-orientation versus cooperation-orientation dimension has also carried the titles "masculinity versus femininity", and "performance-orientation versus cooperation-orientation" (Hofstede \& Pedersen, 1999). The label, in any case, is designed to differentiate those cultures more achievement-oriented from those cultures more cooperationoriented regardless of an individual's gender. Japan is a masculine country, but, so then is the United States (Newman \& Nollen, 1996).

Uncertainty avoidance dimension. Uncertainty avoidance and uncertainty tolerance represent opposite ends of a scale that measures the population's tolerance of ambiguity (Hofstede \& Pedersen, 1999). This dimension centers on ambiguity, and not the tolerance to measurable risks.

Newman and Nollen (1996) state that this dimension has been more criticized than any of the other dimensions and may be a reflection of the time period in which Hofstede identified it: that being the 1960's and 1970's. Still, from prior research, the United States is a weak uncertainty avoidance country and the citizens prefer the discretion that goes with ambiguity (Hofstede, 1980; Newman \& Nollen, 1996). Japan scored strong uncertainty avoidance (Hofstede, 1980).

Long-term dimension. The fifth dimension was added by Hofstede after his original work as a result of further research by Hofstede and Bond (1988). The long-term versus short-term orientation to national culture is also called "Confucian dynamism" (Hofstede, et al., 1990, p. 289). This dimension refers to the position on the scale whereby a national culture considers the future over the present and past, or saving over consuming today (Hofstede, et al., 1990). Asian countries, including Japan, are considered long-term countries characterized by patience, perseverance and respect for the older generations (Newman \& Nollen, 1996).

\section{Reflecting on National Culture at Honda of America Mfg.}

To look at Honda of America, is to see the merging of people from two different national cultures resulting in one financially successful organization. Only in relation to the dimension of achievement-orientation are Japan and the United States on the same side of the theoretical national culture dimension scale.

In Lawrence Miller's (1991) retelling of his visit to Honda of America, he states that Honda of America is unlike other Japanese companies in that there is no high value on age and seniority. Mr. Honda retired because he believed that young men should run the company. This places the Honda of America culture in the same light as the United States ranking on the power dimension. At very least, Honda has found a successful means of merging dissimilar national cultures into a single successful organizational culture.

\section{Organizational Culture}

Theories of organizational culture are covered in this section followed by the review of those theories at the Honda of America automobile plant in Marysville. This section will build on the national culture dimensions to develop the organizational culture constructs.

\section{Organizational Culture Theories}

Schein $(1983,1989)$ established that organizational culture is communicated through company philosophy statements, criteria for promotion, stories of the company heroes, the issues that are important to the leaders of the company, and through the unspoken criteria for determining the appropriate person to fill important slots in the organization. Much of Schein's work compliments Hofstede's regarding the manifestations of culture (Hofstede, et al., 1990): the organizational practices involving symbols, heroes and rituals. 
Newman and Nollen (1996) used Hofstede's national culture dimensions to study the fit between organizational practices and national culture. They found that business performance was better when management practices were in harmony with national culture dimensions.

Still, Hofstede, et al., (1990) describe an organizational, or corporate, culture composed of other elements than those that make up national culture. While they point to disagreement about a definition for organizational culture, they offer the following characteristics of the construct: it is "holistic, historically determined, related to anthropological concepts, socially constructed, soft and difficult to change" (Hofstede, et al., 1990, p.286).

In conflict with Peters and Waterman (1982) who described shared values as the core of organizational culture, Hofstede, et al., (1990) argue that shared perceptions of daily practices are the core of organizational culture. Organizational culture therefore, becomes yet another descriptor of human behavior.

\section{Reflections of Organizational Culture at Honda of America Mfg.}

Miller (1991) wrote that the management practices, structure, systems, skills, style and symbols at Honda of America are consistent with the philosophy of the leadership. The rituals for the newly hired include planting a tree to symbolize support for employment beliefs consistent with the management philosophy. The management style is communicated through stories of heroes. Team size, communication, problem solving skills, reward systems, compensation and positive reinforcement applications are consistent with the leadership's implementation of organizational culture.

\section{Occupational Culture}

This section begins with academic research findings that question the validity of using national culture theory for business. An opposing view that occupational culture contributes more to shaping business is detailed. Once again, the theory is followed by application to Honda of America.

\section{Theory and Occupational Culture}

At this point, it is important to point to studies that question the effect of national culture on business issues. Markoczy (2000) found that being a member of a favored group within the organization plays a larger role in molding business beliefs than nationality or status. From Hofstede, et al., (1990), there is also a role for occupational culture. Occupational culture suggests that socialization during schooling or training in a given field results in the acquisition of both values and practices of importance to members of that occupation (Hofstede, et al., 1990). Occupational culture is then another descriptor of behavior.

\section{Reflections of Occupational Culture at Honda of America Mfg.}

Miller (1991) brings to light instances of people with specific occupations within Honda of America as particular contributors to the success of the company. One example that he points to is the hiring of highly skilled engineering and quality personnel. Engineering occupations are favored at Honda of America. Additionally, the production associates are portrayed as intelligent, skilled and dedicated, but all associates are expected to work with a sense of humor and exhibit high levels of people-to-people skills.

This section provided an opposing theory based view that the occupational culture at Honda of America may be more indicative of important business indicators. Still, Hofstede's view that occupational culture is complimentary to the national and organizational culture is also a supported.

\section{Discussion}

Theories of national, organizational and occupational culture were detailed in the preceding sections. Years of research and expansion of original theories in national and organizational culture provided a basis for this effort. 
Occupational culture theories are relatively new by comparison. Occupational culture provides a possible contradictory position to the thoughts of national culture as important in business applications. One consideration for future research is the impact of these occupational culture indicators on business outcomes.

Evaluating theories in reference to Honda of America Manufacturing furthered this academic review. Examples of situations both supporting and not-supporting existing theories were discussed. Honda of America provides a successful blend of national cultures into an organizational culture that works well for making cars. Further case research may be indicated as a untapped area for additional study.

While the Honda of America case provides one window for critically examining theories, it also is only one limited example of culture combinations. A shortcoming of this review is that it is only a case of one. Another shortcoming is that the review is performed on data collected from secondary sources. While the secondary source of information is not the most desirable means of collecting data, it is less costly to develop and less disruptive to the company being reviewed (Phillips, 1983).

Further areas for research include examination of the theories directly with successful multi-national companies like Honda of America Manufacturing, and equally importantly, with unsuccessful companies. Interview methods will lead to opportunities to clarify the constructs in the theories presented and their business application (Phillips, 1983).

This paper addressed theories of international business, and in particular: national culture, organizational culture and occupational culture. The concepts within each theory were reviewed. Application to the case of Honda of America Manufacturing provided a means of reviewing the academic discussion in a business environment. Finally, future opportunities for further study were offered.

\section{References}

1. Business \& Company Resource Center. (n.d.). Company profile display page. Retrieved February 18, 2003, from Gale Group Web Site: http://0galenet.galegroup.com.novacat.nova.edu/servlet/BCRC?c=1\&ste=\&docNum=DC130926 \&ccmp=H2/18/0.

2. Chappell, L. (2002, August 5). Great plants are not good enough; Nissan, Honda and Toyota push ahead to improve assembly flexibility, just as the Big 3 are closing the gap. Automotive News, 76, 44.

3. Chappell, L. (2002, November 11). Honda talent is home-grown; 20-year strategy builds U.S. success. Automotive News, 77, 17.

4. Chappell, L. (2002, September 23). Honda seeks flexibility over volume in plants. Automotive News, 77, 10.

5. Financial Times Information (2002, August 7). Honda president \& CEO Hiroyuki Yoshino receives fourth annual Wu manufacturing leadership award. PR Newswire, p. NA.

6. Hofstede, G. (1980). Motivation, leadership, and organization: Do American theories apply abroad? Organizational Dynamics, 9(1), 42-63.

7. Hofstede, G. J., \& Pedersen, P. (1999). Synthetic cultures: Intercultural learning through simulation games. Simulation and Gaming, 30(4), 415-440.

8. Hofstede, G., \& Bond, M. H. (1988). The Confucius connection: From cultural roots to economic growth. Organizational Dynamics, 16(4), 4-21.

9. Hofstede, G., Bond, M. H., \& Luk, C. (1993). Individual perceptions of organizational cultures: A methodological treatise on levels of analysis. Organization Studies, 14(4), 483-503.

10. Hofstede, G., Neuijen, B., Ohayv, D. D., \& Sanders, G. (1990). Measuring organizational cultures: A qualitative and quantitative study across twenty cases. Administrative Science Quarterly, 35, 286-316.

11. Kuchinke, K. P. (1999). Leadership and culture: Work-related values and leadership styles among one company's U.S. and German telecommunications employees. Human Resource Development Quarterly, $10(2), 135-154$.

12. Markoczy, L. (2000). National culture and strategic change in belief formation. Journal of International Business Studies, 31(3), 427-442. 
13. Miller, L. (1991). Case 3: Honda: A visit to Marysville. Managing quality through teams. Miller Consulting Group.

14. Newman, K. L., \& Nollen, S. D. (1996). Culture and congruence: The fit between management practices and national culture. Journal of International Business Studies, (4th Qtr.), 753-779.

15. Peters, T. J., \& Waterman, R. H. (1982). In search of excellence: Lessons from America's best-run companies. New York: Harper \& Row.

16. Phillips, J. J. (1983). Advantages and limitations of various data collection methods. In (Ed.), Handbook of training evaluation and measurement methods (p. 92). Houston: .

17. Risen, J. (1988, May 27). Head of Honda plant in Ohio moves higher. Los Angeles Times, p. 3.

18. Schein, E. H. (1983). The role of the founder in creating organization culture. Organization Dynamics, 11, 13-28.

19. Schein, E. H. (1989). Conversation with Edgar H. Schein. Organizational Dynamics, 17, 60-76.

20. Schuler, R S., \& Rogovsky, N. (1998). Understanding compensation practice variations across firms: The impact of national culture. Journal of International Business Studies, 29(1), 159-177.

21. Ting-Toomey, S. (1989). Intergroup communication and simulation in low- and high-context cultures. In D. Crookall \& D. Saunders (1989). Communication and simulation. Clevedon, UK: Multilingual Matters.

22. Zachary, K. (2002, November 1). Not done yet. Ward's Auto World, 38, NA. 